\title{
The Influence of Teacher Training for the Attention of Students with Intellectual Disabilities in the Transitional Period to Adulthood
}

\author{
Silvia Carrascal ${ }^{1, *}$, Yolanda García Rodríguez ${ }^{2}$ \\ ${ }^{1}$ Department of Research, Faculty of Education, Camilo José Cela University, Spain \\ ${ }^{2}$ Research in Doctoral Program, Faculty of Education, Camilo José Cela University, Spain
}

Copyright $\bigcirc 2017$ by authors, all rights reserved. Authors agree that this article remains permanently open access under the terms of the Creative Commons Attribution License 4.0 International License

\begin{abstract}
Nowadays, inclusive schools should be characterized by a high level of commitment in teacher training. To achieve this goal, teachers should be trained in teaching competences in contexts of a great diversity. Their task will be to teach intellectually disabled students by adapting the educational contents through the use of educational resources. In this context, an interdisciplinary training based on integrating social and cultural values is to develop capacities and skills which are related to comprehensive attitudes towards students; attitudes to promote dialogue, as well as a reflection on teacher training combined with an interdisciplinary collaboration. By this way, teachers will assume an educational role based on promoting a more effective teaching process. In the following paper, different renewing methodological proposals are exposed in order to promote the habit to research among teachers. Thus, a more functional learning process in students with intellectual disability will be facilitated according to the features of their educational stage of "Transitional period to adulthood". The goal of this proposal is to carry out the teacher training in educational strategies by adapting didactic resources to the particular student's environment with especial educational needs. Consequently, the appropriate assistance of diversity in classrooms will be finally suited.
\end{abstract}

Keywords Training, Disability, Inclusive Education, Renewing Methodologies

\section{Introduction}

The transitional period to adulthood has been an important object of study for the last decades, focused to suit some objectives related to inclusion; these objectives provide continuity to Secondary Education while facilitating the participation of students at schools. Teachers must be properly trained in order to achieve mastery over the necessary competences faced to integrate intellectually disabled students within schools (Marbán, Montserrat and Morán, 2012) [5]. To make this integration a reality, teachers will adapt some educational tools.

The transitional period to adulthood is one of the most complex challenges for students with intellectual disability in Spain, according to Rosselló and Verger (2008) [9] and Vilá, Pallisera and Fullana (2012) [8] [11] reports. These analyses reveal the importance of inclusion in working life contexts and of some tools to use with intellectually disabled people properly supported. Other jobs are focused to Secondary Education highlighting strategies to suit inclusion of intellectually disabled students within occupational contexts both from educational and psycho- pedagogical point of view.

From scholar education, some technical modifications have to be carried out in order to provide planning for the diversity of students in situations of greater vulnerability by integrating them at schools, according to Jordán, Verdugo and Vicent (2005) [3] report.

In this context, special education schools have a more global perspective: these schools have a longer last in time for the subject of transitional period to adulthood than any other school (4years). This long-term period suits the training in different subjects, human relationships, social skills, personal autonomy, as well as the personal ability of the student through occupational working. In both educational contexts, a specific planning faced to this kind of students has to be established according to the respective education regulations.

\subsection{The Teacher Facing Conceptual Changes about Intellectual Disabilities}

Nowadays, different models related to terminology which 
is cutting on the edge according to the original country where it is being used. Let us briefly review these models: the rehabilitating model actions assume that intellectual disability is scientific, so it has to be treated with specific cares focused to the attention and cares that a disabled person requires; the social model is focused on the fact that the environment has to adapt to the needs of the disabled person by supporting him according to some social rules; the diverse functionality model considers communication as an essential process, so the use of an adapted kind of language with disabled people is at present and in coming situations extremely important. The international classification of Working, Disability and Health (in Spanish, CIF) provides a wider and more positive view of everybody's health status, taking into consideration the fact that it involves more than the consequences of illnesses regarding social and cultural context. It's taken as a useful tool for the statistical analysis applicable to the different situations (Verdugo 2013: 55) [1].

From scholar education, the terminology used to refer to disability, is "students with specific educational needs; students who need a specific educational support". This kind of students has specific educational needs and has to face troubles in the learning process This kind of students has also a high intellectual capacity, and has enrolled late in school or has a personal situation which requires a specific educational attention to make him reach a high level of his personal aptitudes and even the educational aims demanded to every student (Ley Orgánica 8/2013:17179) [4].

Since the great amount of existing terminology on disabled people, it's a challenge for teachers to meet the different demands of students according to the different intervention models which are related to social, educational and sanitary aspects. Teachers need to be properly trained in order to meet the demand of intellectually disabled students in the transitional period to adulthood.

\subsection{Teachers Training on Diversity: Development of their Capacities and Communication Skills on Reflection, Collaboration and Personal Inquiry.}

After secondary education, young students both from regular and specific education schools, get ready for the working life. They do it at home. Participating actively in different community contexts and feeling socially involved will help them get ready to the working life. These concepts are commonly included in the transitional period to adulthood program from an inclusion perspective (Cobb \& Alwell, 2009 [2]; Martínez, 2002 [6]).

The current education law sets out a methodological change from a transversal point of view, which includes social and civil values. In this sense, the principles of 'no discrimination', collaboration and equal opportunities for every student are highlighted.

In this context, in order to establish that principles in students, new specific training actions to adapt educational strategies and inclusion models are essential.
These strategies and models are to suit the interdisciplinary nature faced to the social needs of students at schools and to develop the communication skills of students which are related to positive attitudes for the transitional period to adulthood. These methodological proposals require the development of certain education strategies to facilitate the task of taking decisions and the teaching collaboration structures. In this sense, reflection and personal inquiry has to be suited as a continuous training process through an exchange of teaching experiences and the collaboration of other educational institutions. Thus, it is assumed that a proper teacher training will suit his perception of real education faced to establish a model of teaching competences which suit knowledge, the application of methodologies and solving problems while paying attention to meet the demand of students in the process of transitional period to an active adulthood.

From this methodology, a study to identify other communication skills in teacher training has been carried out. To make it possible, an exchange of teaching experiences as an improvement of permanent training and the development of training competences from a collaborative point of view while paying attention to personal inquiry have been analyzed.

In order to meet the targets to those objectives, different unanswered questions have been set out. The first one is: is the exchange of experiences being carried out in the classroom? The second one is: do teachers consider the need to improve training in the transitional period to adulthood in great diversity contexts?

\section{Materials and Methods}

The transversal method made by teachers working at schools began through the sending of surveys by different school directors. These surveys were submitted by email to teachers

In the data tables which are included in this article with a 95\% confidence interval, every data have been analyzed according to the SPSS Windows statistical package, which is the 17.0 version of the regular IBM program on statistics. This tool has facilitated the statistics report in order to analyze the data obtained in the survey. The data are classified in descriptive data tables. These tables make it easy to classify the data, to carry out segmentation techniques and make a comparison over procedures according to the objectives we want to analyze.

\subsection{Survey Respondents}

The survey has been responded by 174 teachers from Castilla-La Mancha (Albacete, Ciudad Real, Cuenca, Guadalajara and Toledo). 149 of them have responded the survey on-line and 25 have been interviewed about some important items. 
Table 1. Collection of samples

\begin{tabular}{|c|c|c|c|}
\hline & & $\mathrm{n}$ & $\%(\text { IC } 95 \%)^{*}$ \\
\hline \multirow{4}{*}{ Tipe of school } & Public & 68 & $45.6(37.4-53.9)$ \\
\hline & Privat & 44 & $29.5(22.3-37.5)$ \\
\hline & Do not know/Do not answer & 1 & $0.6(0-3.6)$ \\
\hline & State assisted & 39 & $24.1(17.5-31.8)$ \\
\hline \multirow{5}{*}{ Teaching experience } & Less than 5 years & 35 & $23.4(16.9-31.1)$ \\
\hline & From 5 up to 15 years & 50 & $33.5(26.0-41.7)$ \\
\hline & From 16 up to 30 years & 39 & $26.1(19.3-34.0)$ \\
\hline & More than 30 years & 11 & $7.3(3.7-12.8)$ \\
\hline & Do not know/Do not answer & 14 & $9.4(5.2-15.2)$ \\
\hline \multirow{9}{*}{ Specialization of teachers } & Therapeutical Pedagogy & 16 & $10.7(6.2-16.8)$ \\
\hline & Hearing and lenguage & 8 & $5.3(2.3-10.3)$ \\
\hline & Employment guidane & 17 & $11.4(6.7-17.6)$ \\
\hline & Proffessional training & 4 & $2.6(0.7-6.7)$ \\
\hline & Social studies & 11 & $7.3(3.7-12.8)$ \\
\hline & Natural sciences & 6 & $4.0(1.4-8.5)$ \\
\hline & Physical education & 10 & $6.7(3.2-11.9)$ \\
\hline & Plastic art and music & 16 & $10.7(6.2-16.8)$ \\
\hline & Others & 42 & $28.1(21.1-36.1)$ \\
\hline
\end{tabular}

This interview as a way to recollect qualitative data has been used as a complement of the information about the exchange of experiences and collaboration. These two processes are linked to reflection by answering the unanswered points of the survey.

Table 2. Sample of the professional profiles of the survey respondents

\begin{tabular}{|c|c|c|}
\hline Number & Teacher profile & Type of school \\
\hline 9 & Therapeutical pedagogy teacher & Special Education school \\
\hline 1 & Proffessional guiding & Special education school \\
\hline 7 & Elementary education teacher & Childhood and Primary education school \\
\hline 1 & Proffessional guiding & Secondary education high school \\
\hline 2 & Proffessional training teacher & Secondary education high school \\
\hline 5 & Secondary education teacher & Secondary education high school \\
\hline
\end{tabular}

\subsection{Measures}

This study is about the different tasks that have been carried out by applying a qualitative and quantitative methodology, adapting work from reflection and planning the different data. A large proportion of this work has been made thanks to the participation of the 174 teachers, aiming to shape the reality in an educational and social context. In this sense, some criteria for inclusion and exclusion of the table have been used to complete the table.

\subsection{Procedures}

In this study, the process from which the survey was made has been taken into account at every primary, secondary and special education school (regardless of their specific features) within Castilla-La Mancha. Before the intervention, information tasks have been carried out by contacting the different public administration services, as well as the school directors and resource people, such as the respondent teachers, to apply the survey via on-line. According to the descriptive research planning, the recollection of information has been carried out through the survey, the interviews and the fact that an expert team has suited dialogue and reflection. 


\section{Results}

The results obtained from the exchange of experiences as a way to improve teacher training reveal $63,1 \%$ of them don't share their professional experiences with their colleagues at school and 70.4\% don't share them with other teachers outside school. In this context, they paradoxically consider it's important to suit the exchange of experiences for them to improve their training competences. Meanwhile, $88.5 \%$ of teachers think that exchange is insufficient in diversity contexts within Castilla-La Mancha.

Table 3. Confidence interval: $95 \%$ regularly measured. Intercultural experiences which are carried out are not shared.

\begin{tabular}{|c|c|c|c|}
\hline ITEM & & $\mathrm{n}$ & $\%(\mathrm{IC} 95 \%)^{*}$ \\
\hline \multirow{3}{*}{10.} & Do not agree & 54 & $36.2(28.5-44.5)$ \\
\cline { 2 - 4 } & Agree & 94 & $63.1(54.8-70.8)$ \\
\cline { 2 - 4 } & Do not know/Do not answer & 1 & $0.7(0-3.6)$ \\
\hline \multirow{3}{*}{11.} & Do not agree & 43 & $28.9(21.7-36.8)$ \\
\cline { 2 - 4 } & Agree & 105 & $70.4(62.4-77.6)$ \\
\cline { 2 - 4 } & Do not know/Do not answer & 1 & $0.7(0-3.6)$ \\
\hline \multirow{3}{*}{12.} & Do not agree & 6 & $4.1(1.4-8.5)$ \\
\cline { 2 - 4 } & Agree & 142 & $95.3(90.5-98.0)$ \\
\cline { 2 - 4 } & Do not know/Do not answer & 1 & $0.7(0-3.6)$ \\
\hline \multirow{3}{*}{13.} & Do not agree & 16 & $10.8(6.2-16.8)$ \\
\cline { 2 - 4 } & Agree & 132 & $88.5(82.3-93.2)$ \\
\cline { 2 - 4 } & Do not know/Do not answer & 1 & $0.7(0-3.6)$ \\
\hline
\end{tabular}

Regarding the intercultural and methodological proposals in education and other contexts, $89.3 \%$ consider the know-how of these proposals essential to improve their professional practice and their training competences in the existing diversity context, Likewise, 92,6\% consider the intercultural procedures important to provide different focuses to the teaching- learning models that make clear the need to change and open our minds to new realities and cultural perspectives at school. In the same vein, el 91,3\% consider that proposals even more fruitful applied as a complement of reflection in order to improve the teachinglearning process. $79.2 \%$ of the teachers consider training has contributed to personal and joint inquiry, as well as to the application of new teaching-learning strategies and didactic methods according to a diversity context.

Table 4. The exchange of experiences and personal reflection suit teacher training.

\begin{tabular}{|c|c|c|c|}
\hline ÍTEM & & $\mathrm{n}$ & $\%$ (IC 95\%) $^{*}$ \\
\hline \multirow{3}{*}{2.} & Do not agree & 15 & $10.1(5.7-16.0)$ \\
\cline { 2 - 4 } & Agree & 133 & $89.3(83.1-97.3)$ \\
\cline { 2 - 4 } & Do not know/Do not answer & 1 & $0.7(0.0-3.6)$ \\
\hline \multirow{3}{*}{6.} & Do not agree & 10 & $6.7(3.2-11.9)$ \\
\cline { 2 - 4 } & Agree & 138 & $92.6(87.1-96.2)$ \\
\cline { 2 - 4 } & Do not know/Do not answer & 1 & $0.7(0.0-3.6)$ \\
\hline
\end{tabular}

* Confidence interval 95\% regularly measured
In the results obtained regarding the development of teaching competences from the collaboration and personal inquiry model, $91.3 \%$ of the teachers consider collaborative reflection as an important aspects to improve their permanent training by applying some strategies on inquiry and communication skills which suit dialogue. For $79.2 \%$, reflection and inquiry help them to carry out comprehension tasks, as well as to apply more creative strategies by using new information they have about social and cultural values and didactic methods which are more and more faced to diversity.

Table 5. By facilitating collaborative reflection, attention to diversity is better

\begin{tabular}{|c|c|c|c|}
\hline ÍTEM & & $\mathrm{N}$ & $\%($ IC 95\%)* \\
\hline \multirow{3}{*}{17.} & Do not agree & 12 & $8.0(4.2-13.6)$ \\
\cline { 2 - 4 } & Agree & 136 & $91.3(85.5-95.2)$ \\
\cline { 2 - 4 } & Do not know/Do not answer & 1 & $0.7(0-3.6)$ \\
\hline \multirow{3}{*}{23.} & Do not agree & 30 & $20.1(14.0-27.4)$ \\
\cline { 2 - 4 } & Agree & 118 & $79.2(71.7-85.4)$ \\
\cline { 2 - 4 } & Do not know/Do not answer & 1 & $0.7(0-3.6)$ \\
\hline
\end{tabular}

* Confidence interval: 95\% regularly measured

In the same case, $98 \%$ of the respondent teachers think that paying attention to the different specific needs of students is suitable for diversity; some processes and strategies are being carried out in order to improve teacher training. $94 \%$ think personal inquiry is being suited in order to become open-minded and compromised teachers. 96.6\% think creative and reflexive professional practice is being reinforced; they also consider that having the know-how of the teaching practice in diversity contexts reinforces social and cultural values, such as the solidarity coexistence, opening, compromise and common empathy, which are existing demands at schools nowadays. 96\% think the specific training on intercultural aspects prepares teachers to pay attention to intercultural diversity; they also think that this is important to acquire new values as tolerance, coexistence, mind- opening, compromise and plural empathy. Likewise, 79,2\% agree that this training helps teachers pay attention to diversity; this percentage also think that new researching processes on the professional practice in collaboration with other teachers have been carried out. This processes, as they state, make teachers meet the demand of students in a more compliant and coherent way. 
Table 6. Training as a process of personal and collaborative inquiry

\begin{tabular}{|c|c|c|c|}
\hline & & $\mathrm{n}$ & $\%(\mathrm{IC} 95 \%)^{*}$ \\
\hline \multirow{3}{*}{18.} & Do not agree & 2 & $1.3(0.1-4.7)$ \\
\cline { 2 - 4 } & Agree & 146 & $98.0(94.2-99.5)$ \\
\cline { 2 - 4 } & Do not know/Do not answer & 1 & $0.7(0.0-3.6)$ \\
\hline \multirow{2}{*}{19.} & Do not agree & 8 & $5.4(2.3-10.3)$ \\
\hline & Agree & 140 & $94.0(88.8-97.2)$ \\
\hline 20. & Do not know/Do not answer & 1 & $0.7(0.0-3.6)$ \\
\hline & Agree & 4 & $2.7(0.7-6.7)$ \\
\hline & Do not know/Do not answer & 1 & $0.7(0.0-3.6)$ \\
\hline 21. & Do not agree & 5 & $3.4(1.0-7.6)$ \\
\hline & Agree & 143 & $96.0(91.4-98.5)$ \\
\hline & Do not know/Do not answer & 1 & $0.7(0.0-3.6)$ \\
\hline 22. & Do not agree & 30 & $20.1(14.0-27.4)$ \\
\hline & Agree & 118 & $79.2(71.7-85.4)$ \\
\hline & Do not know/Do not answer & 1 & $0.7(0.0-3.6)$ \\
\hline 23. & Do not agree & 30 & $20.1(14.0-27.4)$ \\
\hline & Agree & 118 & $79.2(71.7-85.4)$ \\
\hline & Do not know/Do not answer & 1 & $0.7(0.0-3.6)$ \\
\hline
\end{tabular}

*Asymptotic $95 \%$ confidence interval using normal distribution.

\section{Discussion}

The results obtained in this study are explained in the research on the situation of disabled people, which pays attention to the challenges they will have to face (shown in an overview of the year 2020- Mara ban, Moran, Montserrat and Rodríguez 2012 report) on the training of students on the process "from school to a job"

Another important referent is the education for all monitoring report, which assumes the importance of teaching in education quality. This report also highlights the fact that governments have to contribute to improve teaching competences and allow teachers to take part in the professional decisions in which they are involved (from UNESCO 2015 documents). The different tests that have been checked show the need to take decisions on the situation of disabled students in Secondary education.

\section{Conclusions}

The analyses show that teachers consider important the development of teaching competences in order to meet the demand of students in the transitional period to adulthood. In this context, a more collaborative pedagogical model, as well as based on personal inquiry, is essential to suit the learning process and exchange interdisciplinary experiences. The analysis of the context reveals that the performances which education carries out on the period "from school to a job" are insufficient. In order to repair this problem, we have new education plans to carry out new methodologies and possibilities for learning in great diversity contexts. Since the enormous size of Castilla-La Mancha, even it would have suited teachers implication, it's been impossible to focus the different respondents in a more personal way.

The respondents contributions can suit the production of teacher competences planning to meet the need of new teaching possibilities and other plans to meet the demand of the working and occupational environment. That's why the challenge for future researches starts from the need to review the permanent training model for teachers from inclusion, which is a way to improve teaching quality.

\section{REFERENCES}

[1] M.A. Verdugo. Discapacidad Intelectual: definición clasificación y sistemas de apoyo. Undécima Edición. Salamanca, Alianza, 2012.

[2] R. B. Cobb, M. Alwell. Transition Planning. Coordinating Interventions for Youth with Disabilities, Career Developmental for Exceptional Individuals, Vol. 32, No 2, 70-81, 2009.

[3] B. Jordán, M.A. Verdugo, C. Vicent. Análisis de la Evolución del Empleo con Apoyo en España. Madrid, Real Patronato sobre Discapacidad. Documentos 59/2005.

[4] Ley 8/2013, de 9 de diciembre, para la Mejora de la Calidad Educativa. BOE núm. 295, de 10 de diciembre de 2013 (17179-17180). Cap. I. Alumnado con necesidades de apoyo educativo y de necesidades educativas especiales. Madrid, Ministerio de Cultura y Deporte.

[5] G. V. Marbán, C. J. Montserrat A. E. Morán, C.G. Rodríguez. El sector de la discapacidad: realidad, necesidades y retos futuros. Madrid, Cinca, 2012.

[6] N. Martínez. Juventud y discapacidad. Programas y herramientas para facilitar la transición a la vida adulta. Bilbao, Mensajero, 2002.

[7] Organización Mundial de la Salud. Clasificación Internacional de las Deficiencias y Minusvalías (CIF). Madrid, Ministerio de Trabajo y Asuntos Sociales, 2001.

[1] Secretaría General: Asuntos Sociales. Instituto de Migraciones y Servicios Sociales (IMSERSO). From http://www.imserso.es/InterPresent2/groups/imserso/docume nts/binario/435cif.pdf

[8] M. Pallisera, J. Fullana, M. Vilá. La inserción laboral de personas con discapacidad. Desarrollo de tres investigaciones acerca de los factores favorecedores de los procesos de inserción. Revista de Investigación Educativa, Vol. 23, No 2, 295-313, 2005.

[9] M.R. Rosselló, S. Verger. La inclusión de personas con discapacidad en el lugar de trabajo en las Islas Baleares. Revista Europea de Formación Profesional, Vol. 45, 181-200, 2008.

[10] UNESCO. Informe de seguimiento de la Educación Para Todos en el Mundo 2000-2015. Retos y desafíos. París, 
Organización para las Naciones Unidas para la Educación, la Ciencia y la Cultura, 2015.

[11] M. Vilá, M. Pallisera, J. Fullana. La inclusión laboral de los jóvenes con discapacidad intelectual: Un reto para la orientación psicopedagógica. Revista Española de Orientación y Psicopedagogía, Vol. 23, No 1, 85-93, 2012. 